\title{
Laboratory diagnosis of Chagas' heart disease
}

\author{
Division of Infectious Diseases, Institute of Tropical Medicine \\ Immunology and Seroepidemiology Laboratory, Faculdade de Medicina da \\ Universidade de São Paulo - São Paulo, Brazil
}

\begin{abstract}
The laboratory diagnosis of Chagas' disease is a complex one. Factors relating to the host immune response and the antigenic variability of $T$. cruzi must be considered in the final interpretation of test results. Parasitologic methods for detecting $T$. cruzi, immunologic methods for detecting $T$. cruzi antigens in different biological fluids and serologic tests for detection and quantification of different classes of immunoglobulins are well standardized and used in the diagnosis of the acute or chronic phase of the disease. Xenodiagnosis is the most common parasitologic test employed, although it detects only $50 \%$ of infections in the chronic phase. Indirect immunofluorescence for detecting $\mathrm{lgG}$ and $\mathrm{IgM}$ antibodies, hemagglutination and enzyme immunoassay are the serologic tests most frequently employed for diagnosis, to screen blood donors and for seroepidemiologic studies. An important caveat to be remembered is that serologic tests provide only a probable diagnosis, which depends on the prevalence of Chagas disease, as well as on the sensitivity and specificity of the test employed. The use of well defined specific antigens, obtained through recombinant methods or chromatography, opens an important field for the development of very specific tests, without significant loss of sensitivity.
\end{abstract}

UNITERMOS: Chagas. Laboratory. Diagnosis.

\section{INTRODUCTION}

1 Trypanosoma cruzi, the etiologic agent of Chagas' disease, is a protozoan found in different animal species. Human disease is acquired through insect vectors belonging to the subfamily Triatomina, family Reduviidae, order Hemiptera.

In Latin America, the most important vectors implicated in the transmission of the rural form of the disease are Triatoma infestans, Pastrongylus megistus, Rhodnius prolixus, Triatoma dimidiata and Triatoma brasiliensis. T. cruzi belongs to the Stercoraria session of the family Trypanosomatidae, which includes

\author{
Address for correspondence: \\ Antonio Walter Ferreira \\ Instituto de Medicina Tropical de São Paulo
}

Av. Dr. Enéas de Carvalho Aguiar, 470

São Paulo - SP - Brasil - CEP 05403-000 trypanosomes which develop in the digestive tract of the vectors and are transmitted through direct contact with the feces of the triatoma bug. $T$. cruzi has great antigenic variation, which makes difficult the study of the epidemiological, clinical, pathological, laboratory and therapeutic aspects of Chagas' disease. In urban areas, transmission of the disease through blood products is of great concern and results from the migration of infected individuals from endemic areas to industrialized centers. Congenital and accidental transmission are also been described in the literature.

\section{LABORATORY DIAGNOSIS}

The laboratory diagnosis of Chagas' disease is accomplished by methods which demonstrate the presence of the parasite in the blood, directly or indirectly (parasitologic methods) and through the detection of serum anti-T.cruzi antibodies. 


\section{PARASITOLOGIC METHODS}

These methods can be employed to diagnose either the acute or chronic phase of disease.

In the acute phase of Chagas' disease (first 6 weeks), methods which demonstrate the presence of trypanosomes in the bloodstream are employed. This can be accomplished through the examination of a thin peripheral blood smear under a microscope. Other variations of this method, such as preparing thick blood smears or concentrating the parasite, increase the likelihood of detection. A promising technique called Quantitative Buffy Coat (QBC method), which is widely used to diagnose infections with plasmodia, has been successfully applied to detect trypanosomes, especially in patients with very low levels of parasitemia. In newborns with congenital $T$. cruzi infection, many authors recommend the search for trypanosomes in bone marrow and spinal fluid. Amastigote forms have also been demonstrated in the chronic phase of the disease, mainly in muscle tissue. The sensitivity of the methods which directly demonstrate the presence $\mathrm{T}$. cruzi in the bloodstream ranges from 50 to $95 \%$ and is influenced by several factors, ranging from the quality of the microscopic equipment to the expertise of the observer.

In the chronic phase of the disease, xenodiagnosis and blood culture (indirect methods) are employed.

Xenodiagnosis is done through the use of nymph vectors, bred in laboratory and fed with blood from fowl resistant to $T$. cruzi infection. In this technique, the nymphs are allowed to have a blood meal through the patient's skin. About 40 nymphs are put in 4 boxes and kept at $28^{\circ} \mathrm{C}$, with $85 \%$ air humidity. After 4 to 6 weeks, the gut of the insect and its contents are examined for the presence of $T$. cruzi, under a microscopy. The sensitivity of this method is $85-100 \%$ in the acute phase and about $50 \%$ in the chronic phase. A variant of the classical method (artificial xenodiagnosis) was introduced to avoid hypersensitivity reactions in susceptible patients. Nymph vectors are allowed to feed on blood from the suspected patients, which is kept in small dialysis bags, usually made from the intestine of pigs. Many authors report that sequential readings, at $30,60,90$ days increase positive results in the chronic phase of the disease.

Blood culture, though an insensitive technique, is useful in isolating $T$. cruzi strains for studies of biochemical and immunochemistry typing. When used for diagnostic purposes, it detects approximately $50 \%$ of cases in the chronic disease.

Other diagnostic methods such as animal innoculation (mice, guinea pigs) and in vitro cell culture are seldom employed (7).
SEROLOGIC DIAGNOSIS

Serologic tests are widely used to: screen suitable blood donors, as markers to monitor therapy, to confirm or exclude clinical suspicion of Chagas' disease, in epidemiologic studies and to screen infected industry workers. Serologic tests give only an estimate of probability of disease and their final interpretation is influenced by numerous factors, like the sensitivity and specificity of the test and the prevalence of Chagas'disease in the population being tested.

Many standardized tests have been used to diagnose Chagas' disease. It is important to bear in mind the great antigenic complexity of T. cruzi. This characteristic dictates the host's immune response to the disease and has led to researchers for different markers of disease. Through peptide technology and molecular biology techniques, many investigators are attempting to identify highly specific antigenic epitopes.

Stolf, in 1992, described the ideal antigen as the one which would be present in all strains from different endemic areas, highly immunogenic, not present in other pathogenic microorganisms, stable and easy to be obtained for use in serologic tests (19). Next, we will make a discussion of the different tests employed in the serologic diagnosis of Chagas disease. It is worth remembering that, for the different serologic tests, there is an overlap in the reactivity curves of infected and non-infected individuals. By changing the cut-off point of the test, one can achieve maximum sensitivity or specificity. The point where the curves intersect defines the values of sensitivity and specificity (18).

\section{1) Complement fixation}

Introduced by Guerreiro and Machado in 1913, the complement fixation test has only historic value, though it is still used by some to screen blood donors and for diagnostic purposes. The technical complexity of this test, which requires the daily standardization of its components - antigen, hemolytic system and complement - interferes in its reproducibility. Its low level of sensitivity and specificity have also contributed to the low popularity of this test.

\section{2) Precipitation test}

The different variations of this test, though highly specific, have poor sensitivity. 
It is mainly used in the study of the different antigenic components of $T$. cruzi. Counterimmunolectrophoresis has been the preferred method for diagnosis and seroepidemiologic studies. Breniere, using serum with the component 5 of $T$. cruzi obtained from rabbits, obtained a sensitivity of $85 \%$ and specificity of $100 \%$, even when testing sera from patients with leishmaniasis (1). Requejo et al. recently standardized and tested the DIG-ELISA assay, which is an association between the immunoassay and the agar diffusion test. The authors found the test to have high sensitivity and specificity and recommended it for screening and for seroepidemiologic surveys. Multicenter studies are necessary to validate this test (18).

\section{3) Agglutination tests}

This test, with its variants, has been widely used in the diagnosis of Chagas disease.

\section{3a) Direct Agglutination}

Several authors have described the use of this test, comparing it to immunofluorescence. Vattuone and Yanowsky, employing a suspension of epimastigote forms of $T$. cruzi, treated with enzymes and fixed with formalin, obtained good sensitivity in the detection of antibodies in the acute phase of Chagas' disease (20). Harith et al. standardized the microagglutination test, which employed epimastigote forms of $T$. cruzi, treated with tripsin and stained with Coomasie-Blue. Treatment of the 2 sera with mercaptoethanol was critical for the detection of specific antibodies. The sensitivity and specificity of the test were very high. A drawback of the agglutination test is the large amount of parasites necessary to prepare the antigenic suspension (12).

\section{3b) Hemagglutination}

This test is widely used for diagnosis, screening and seroepidemiologic studies. In the test, erythrocytes from mammals or fowl are treated with formalin and sensitized with antigenic components, partially or completely soluble. The product, lyophilized or in suspension, has excellent stability in adverse temperature conditions (5). The test, either quantitative or qualitative, is performed in microtiter plates (13), with the use of different antigenic extracts. The best results are obtained with alkaline and sonicated extracts. The treatment of the 2 sera with mercaptoethanol increases the specificity of the test. The hemagglutination test was studied by Neal and Miles, who used the Y strain of $T$. cruzi, grown in LIT media. They tested diluted blood, collected in paper filter, from different populations from Latin American countries (16).
No regional differences in antibody response were observed. Because of its simplicity and low cost, the hemagglutination test is recommended for screening blood donors. In Brazil, well standardized kits from different manufacturers are commercially available.

\section{3c) Latex agglutination}

Though a very promising test, the latex agglutination test was released in Brazil without proper standardization. False-positive and false-negative results, coupled with poor reproducibility, led to the discontinuation of this test by the manufacturer. With the current possibility of creating covalent bonds between $T$. cruzi antigens and free radicals present in the latex particles, new perspectives for obtaining a new test with good stability, low cost, ease of use and reliable sensitivity and specificity have appeared.

\section{4) Immunofluorescence}

The indirect immunofluorescence test is usually performed with epimastigote forms of the Y strain of $T$. cruzi, obtained from cultures of the parasite in LIT medium. The formalin treated trypanosomes are then fixed in glass slides and incubated in diluted serum for 30 minutes at $37^{\circ} \mathrm{C}$. After proper washings, the slides are incubated with fluorescent conjugate (sheep or goat serum anti-human $\mathrm{IgG}$ or IgM, labeled with fluorescein isothiocyanate). After another incubation and washings, the slide is read with the use of a fluorescence microscope (6). The immunofluorescence test for the detection of IgG anti-T. cruzi antibodies is considered to be the gold standard in the serologic diagnosis of Chagas' disease (3).

Antigenic variation has been observed in the different parasitic stages of $T$. cruzi. Camargo found higher antibody titers with the tripomastigote than with epimastigote forms (2). Primavera et al. compared epimastigote with tripomastigote forms of $T$. cruzi and concluded that the amastigotes are more reactive for the detection of IgA antibodies, especially in patients with the digestive form of the disease (17). Levy standardized the in situ immunofluorescence test with tripomastigote forms, in order to detect membrane epitopes and to follow persistent infections. The test has effectively substituted the complement lysis reaction (15).

Different factors may affect the results of the immunofluorescence test: the quality of the optical equipment and of the antigens, the definition of what constitutes a positive test. These factors should be taken into account and the test should be rigorously standardized in order to obtain reliable results (10). 


\section{5) Enzyme immunoassay}

In 1975, Ferreira standardized the immunoperoxidase test, using formalin fixed epimastigote forms of $T$. cruzi, formalin fixed in glass slides as antigen and enzymatic conjugate (sheep or goat serum conjugated to peroxidase).

After incubation with diluted serum and conjugate, the complex is revealed with substrate and hydrogen donors. The method had the same sensitivity and specificity of the immunofluorescence test. The advantage is that the resulting color development may be visualized with an optical microscope, thus reducing the cost of the test (11).

The use of the enzyme linked immunosorbent assay (ELISA) for the diagnosis of Chagas disease was described by Voller et al. The test was standardized in microtiter plates, adsorbed with soluble T. cruzi antigens. After incubation with serum and enzymatic conjugate, color develops in the supernate after addition of substrate and hydrogen donors. The intensity of color development is measured by spectrophotometry (21).

Due to its good sensitivity and specificity and because it is automated, the standardized enzyme immunoassay has opened new perspectives in the serologic diagnosis of Chagas' disease. The possibility of employing very specific antigenic components, obtained through physicochemical or recombinant methods, is under investigation by several scientists around the world (4). Like the hemagglutination test, well standardized reagents are commercially available and are especially useful for screening blood donors (9).

\section{METHODS FOR DETECTING ANTIGEN IN BODY FLUIDS}

The detection of $T$. cruzi antigens in body fluids is of great importance in the confirmation of infection, especially when the serologic tests or parasitologic methods are negative.

Tests based on precipitation, counterimmunoelectrophoresis or immunodifusion, though highly specific, have low sensitivity, becoming useful in the confirmation and prognosis of disease. The enzyme immunoassay, capture or double sandwich, has proved useful in the detection of T. cruzi antigens in blood or urine, confirming a suspected diagnosis and monitoring the efficacy of anti-Chagas therapy. Some authors believe that the detection o $T$. cruzi antigens in urine is useful in the diagnosis of congenital Chagas' disease. Katzin et al. have described a quick agglutination test to detect $T$. cruzi antigens in patients in the chronic phase of the disease. In this test, horse serum with anti- $T$. cruzi antibodies linked to nitrocellulose micelles reacts with small amounts of antigens present in biologic fluids. Though the test appeared to be very sensitive, further studies are necessary to confirm the results found in the article (14).

\section{ReSUMO}

O diagnóstico de laboratório da doença de Chagas apresenta elevado grau de complexidade. Fatores relacionados com a resposta imune do hospedeiro e fatores relacionados com as diferenças antigênicas do parasita devem ser considerados para a avaliação final do resultado. Métodos parasitológicos ou imunológicos para a pesquisa de $T$. cruzi ou de seus componentes em diferentes fluidos biológicos e testes sorológicos para a pesquisa e quantificação de diferentes classes de imunoglobulinas têm sido padronizados visando o diagnóstico das diferentes fases, aguda, intermediária ou inaparente e crônica da doença. Dos métodos parasitológicos, o xenodiagnóstico, natural ou artificial, é o mais utilizado, embora na fase crônica somente $50 \%$ dos casos sejam detectados. Nos testes sorológicos, ênfase tem sido dada a imunofluorescência indireta para a pesquisa de anticorpos IgG e lgM, ao teste de hemaglutinaçāo, pelo baixo custo e ao teste imunoenzimático, pela possibilidade de automação. Dado que os resultados obtidos nos testes sorológicos fornecem diagnóstico de probabilidade, fatores como a prevalência da doença e a sensibilidade e especificidade dos testes devem ser considerados. A possibilidade da utilização de antígenos definidos, obtidos por métodos físico-químicos, biologia molecular ou síntese, abre perspectivas para a padronização de testes com alta especificidade, sem perda significativa da sensibilidade. 


\section{REFERENCES}

1. BRENIERE, S.F.; CARLIER, Y.; CARRASCOI, R. et al. Specific immunodiagnosis of Chagas' disease: immunodifusion test using a specific serum antiTrypanosoma cruzi component 5. Trop Geogr Med 39:2816, 1987.

2. CAMARGO, M.E. - American trypanosomiasis (Chagas' Disease). In: Balows A, Hausler Jr. WJ, Ohashi M, Turano A. Laboratory Diagnosis of Infectious Diseases. Principles and Practice. New York: Springer-Verlag 1988. p. 744-53.

3. CAMARGO, M.E. \& AMATO NETO, V. - AntiTrypanosoma cruzi IgM antibodies as serological evidence of recent infection. Rev Inst Med Trop São Paulo 16:2002, 1974.

4. CAMARGO, M.E.; FERREIRA, A.W.; PERES, B.A.; PREVIATO, L.M. \& SCHARFSTEIN, J. - Trypanosoma cruzi antibodies. In: Bergmeyer, Methods of Enzymatic Analysis 11:368-81, 1986.

5. CAMARGO, M.E.; HOSHINO, S. \& SIQUEIRA, G.R.V. Hemagglutination with preserved, sensitized cells, a practical test for routine serologic diagnosis of American Trypanosomiasis. Rev Inst Med Trop São Paulo 15:81-5, 1973.

6. CAMARGO, M.E. \& SOUZA, S.L. - The use of filter paper blood smears in a practical fluorescent test for American trypanosomiasis serodiagnosis. Rev Inst Med Trop São Paulo 8:255-8, 1966.

7. CHIARI, E. - Diagnostic test for Chagas' disease. Parasitological diagnosis. In: Wendel, S.; Brener, Z.; Camargo, M.E. \& Rassi, A. - Chagas disease (American Trypanosomiasis): its impact on transfusion and clinical medicine. ISBT Brazil, 1992. p. 153-64.

8. FERREIRA, A.W. - Diagnostic tests for Chagas' disease. Serological diagnosis. Tests for Chagas' disease serodiagnosis: a review. In: Wendel, S.; Brener, Z.; Camargo, M.E. \& Rassi, A. - Chagas disease (American Trypanosomiasis): its impact on transfusion and clinical medicine. ISBT Brazil, 1992. p. 179-94.

9. FERREIRA, A.W.; BELEM, Z.R.; MOURA, M.E.G \& CAMARGO, M.E. - Aspectos da padronização de testes sorológicos para a Doença de Chagas: um teste imunoenzimático para a triagem de doadores de sangue. Rev Inst Med Trop São Paulo 33: 123-8, 1991.

10. FERREIRA, A.W.; CAMARGO, M.E. \& NAKAHARA, O.S. - Aplicação do teste ELISA ao diagnóstico serológico da doença de Chagas. Estudo comparativo com o teste de immunofluorescência em amostras de sangue colhidas em papel de filtro. Abstracts Congresso Internac. Doença de Chagas $1979.210 \mathrm{p}$.
11. FERREIRA, A.W.; CAMARGO, M.E. \& NAKAHARA, O.S. - Trypanosoma cruzi: Immunoperoxidase antibody test for serologic diagnosis. Experimental Parasitology 37: 1317, 1975.

12. HARITH, A.E.; LAARMAN, J.J.; MINTER-GOEDBLOED, E.; KAGER, P.A. \& KOLK, A.H.J. - Trypsin-treated and coomassie blue-stained epimastigote antigen in a microagglutination test for Chagas' disease. Am J Trop Med Hyg 37:66-71, 1987.

13. HOSHINO-SHIMIZU, S.; CAMARGO, M.E. \& NAGASSE, T.K. - A stable polysaccharide-hemagglutination reagent for the diagnosis of acute or recent Trypanosoma cruzi infections. Rev Inst Med Trop São Paulo 20:208-12, 1978.

14. KATZIN, A.M.; MARCIPAR, A.; FREILIJ, H.; CORRAL, R. \& YANOVSKY, J.F. - Rapid determination of Trypanosoma cruzi urinary antigens in human chronic Chagas' Disease by agglutination test. Experimental Parasitology, 1989. p. 208-15.

15. LEVY, A.M.A. - Padronização e avaliação do teste de immunofluorescência com tripomastigotas fixados "in situ" na detecção de anticorpos indicadores da persistência da infecção em chagásicos crônicos. São Paulo, 1991 [Tese de Mestrado - Universidade de São Paulo].

16. NEAL, R.A. \& MILES, R.A. - Indirect haemagglutination test for Chagas' disease, with a simple method for survey work. Rev Inst Med Trop São Paulo 12:325-32, 1970.

17. PRIMAVERA, K.S.C.; HOSHINO-SHIMIZU, S.; UMEZAWA, E.S.; PERES, B.A.; MANIGOT, D.A. \& CAMARGO, M.E. - Immunoglobulin A antibodies to Trypanosoma cruzi antigens in digestive forms of Chagas' disease. J Clin Microbiol 26: 2101-4, 1988.

18. REQUEJO, H.I.Z.; NAKAMURA, P.M.; VAZ, A.J. et al. Diffusion-in-gel enzyme-linked immunosorbent assay (DIGELISA) for Chagas' disease serodiagnosis. Brazilian J Med Biol Res 24:471-83, 1991.

19. STOLF, A.M.S. - Diagnostic tests for Chagas' disease. Serological diagnosis. Trypanosoma cruzi antigens for serodiagnosis. In: Wendel, S.; Brener, Z.; Camargo, M.E. \& Rassi, A. - Chagas' disease (American Trypanosomiasis): its impact on transfusion and clinical medicine. ISBT Brazil 1992. p. 195-206.

20. VATTUONE, N.H. \& YANOVSKY, J.F. - Trypanosoma cruzi: agglutination activity of enzyme-treated epimastigotes. Exp Parasit 30:349-55, 1971.

21. VOLTER, A.; DRAPER, C.; BIDWELL, D.E. \& BARTLETT, A. - A microplate enzyme-linked immunosorbent assay (ELISA) for Chagas disease. Lancet 1:426-9, 1975. 